(c) American Dairy Science Association, 2004.

\title{
Effect of Age at First Calving on Some Productive and Longevity Traits in Iranian Holsteins of the Isfahan Province
}

\author{
M. A. Nilforooshan and M. A. Edriss \\ Department of Animal Science, \\ Isfahan University of Technology, Isfahan 84154
}

\begin{abstract}
Production and pedigree data of Iranian Holsteins were collected from 1991 to the end of 2001 on 45 herds in Isfahan province. Data on culled cows (birth and culling dates) were used to estimate the effect of age at first calving on total lifetime and productive life; and the effect of age at first calving on first-lactation yields was estimated from corrected $(2 \times 305 \mathrm{~d})$ firstlactation records of 12,082 dairy heifers that calved between 1995 and 2001. The estimate of heritability of age at first calving obtained in this study was 0.086 . This low heritability indicates the importance of using available information on relatives for selection on this trait. Age at first calving significantly affected all the traits investigated, including: milk yield, fat yield, fat percentage, lifetime, and productive life. Results indicated a positive effect of reducing age at first calving on milk yield and productive life, although reducing age at first calving to 21 mo of age had a negative effect on yields of milk and milk fat. Lifetime did not show a similar trend with age at first calving. However, a slight positive phenotypic correlation (0.052) was detected between age at first calving and lifetime. We conclude that due to negative effects of age at first calving on productive life and because of optimum age at first calving for milk yield was 24 mo in this study, the reduction of age at first calving to 24 mo of age could be an effective management practice.
\end{abstract}

(Key words: age at first calving, milk yield trait, lifetime, productive life)

\section{INTRODUCTION}

Reproductive efficiency of a cow is measured by factors such as age at first calving, calving interval, days open, and number of services per conception (Dematawewa and Berger, 1998). Age at first calving is an environmental factor influencing milk yield and milk

Received September 10, 2003.

Accepted January 6, 2004

Corresponding author: M. A. Edriss; e-mail: edriss@cc.iut.ac.ir. composition (Pirlo et al., 2000). Decreasing age at first calving has a positive effect on genetic progress because the generation interval decreases and progeny tests of sampling bulls are carried out earlier (Pirlo et al., 2000). Reduction of age at first calving can also decrease replacement expenses. Estimates of all expenses associated with replacement are approximately $20 \%$ of total production costs (Heinrichs, 1993). Reducing age at first calving can reduce feed costs and allow an earlier return on investment (Gardner et al., 1988). Mourits et al. (1997) demonstrated that reducing age at first calving from 26 to 22 mo reduced feed costs (from weaning to first calving) of $\$ 42$ to $\$ 119$ per animal. Pirlo (1997) estimated the rearing costs in Italy for heifers calving at different ages (average age at first calving $=26 \mathrm{mo}$ ), after considering all expenses including feeding, livestock, fixed costs, labor, calf value, and mortality. Rearing costs for heifers calving at $24,26,28$, and 30 mo were $\$ 2062, \$ 2164, \$ 2290$, and $\$ 2411$, respectively.

Theoretically, reduction of age at first calving can increase the number of calves per cow, but dystocia can be an inhibiting factor that may reduce the livability of calves (Martinez et al., 1983; Thompson et al., 1983). Dystocia also might make the calves susceptible to infections because of reduced absorption of immunoglobulins (Donovan et al., 1986). Simerl et al. (1991) found frequency of dystocia to be greater for older $(>27$ mo) heifers as well as for younger $(<22 \mathrm{mo})$ heifers.

Average age at first calving has not been reduced much during the last decades because of the belief that early calving is harmful to milk yield and longevity (Pirlo et al., 2000). Although reduction of age at first calving is one of the most effective strategies for reducing replacement costs, most dairy farmers remain skeptical of calving heifers at ages less than 24 mo (Pirlo, 1997). Pirlo et al. (2000) reported that reduction of age at first calving has a negative effect on firstlactation milk yield and milk fat percentage.

Vukasinovich et al. (2001) reported that the effect of age at first calving did not have a large influence on the length of productive life. Gill and Allaire (1976) suggested that optimal age at first calving for total lifetime performance is 22.5 to 23.5 mo. In the Braun- 
vieh breed, the relative culling risk increases linearly with increasing age at first calving, but in Holsteins and Simmentals, this effect is more curvilinear, with slightly increased risk for cows that calve very early, and especially very late. Greater culling risk for older ages at first calving may be related to reproductive problems (Vukasinovich et al., 2001).

The objective of this study was to estimate the heritability of age at first calving and the effect of age at first calving on milk yield, milk fat yield, milk fat percentage, lifetime, and productive life in Iranian Holsteins in the Isfahan province.

\section{MATERIALS AND METHODS}

Data. For this study, data were provided by the Animal Breeding Center of the Ministry of Agriculture in the Isfahan province. The data were comprised of production and pedigree databases on Iranian Holsteins in the Isfahan province that calved between 1991 and the end of 2001 in 45 herds. Age at first calving was defined to be 21 to $39 \mathrm{mo}$ of age, and the proportion of the data on heifers that calved out of this range was excluded. To estimate the effect of age at first calving on total lifetime (birth and culling dates) and productive life, the available data on culled cows were used. Milk yield, fat yield, and fat percentage records were adjusted to $305 \mathrm{~d}$ and twice daily milking $(2 \times 305 \mathrm{~d})$.

Due to incomplete records, first-lactation records of 12,082 dairy heifers that calved during 1995 to the end of 2001 were used to estimate the effect of age at first calving on first-lactation yields.

Statistical analysis. Statistical analyses of all traits considered in this study were performed using the general linear models procedure (SAS Inst. Inc., Cary, NC).

The following models were used in order to obtain variance components:

$$
\mathbf{Y}_{\mathrm{ijklm}}=\underset{\text { calving })}{\boldsymbol{\mu}}+\mathbf{S I}_{\mathrm{i}}+\mathbf{H Y S}_{\mathrm{j}}+\varepsilon_{\mathrm{ijklm}}(\text { for age at first }
$$

$$
\begin{aligned}
\mathbf{Y}_{\mathrm{ijklm}}= & \boldsymbol{\mu}+\mathbf{S I}_{\mathrm{i}}+\mathbf{H Y S}_{\mathrm{j}}+\mathbf{A F C}_{1}+\varepsilon_{\mathrm{ijklm}}(\text { for milk } \\
& \text { yield, fat yield, and fat percentage }) \\
\mathbf{Y}_{\mathrm{ijklm}}= & \boldsymbol{\mu}+\mathbf{S I}_{\mathrm{i}}+\mathbf{H Y S}_{\mathrm{j}}+\mathbf{F P}_{\mathrm{k}}+\mathbf{A F} \mathbf{C}_{1}+\varepsilon_{\mathrm{ijklm}} \\
& \text { lifetime and productive life })
\end{aligned}
$$

where

$$
\begin{aligned}
\mathbf{Y}_{\mathrm{ijklm}} & =\text { record of the cow, } \\
\boldsymbol{\mu} & =\text { overall population mean } \\
\mathbf{S I}_{\mathrm{i}} & =\text { effect of sire I, } \\
\mathbf{H Y S}_{\mathrm{j}} & =\text { effect of herd-year-season } \mathrm{j}, \\
\mathbf{F P}_{\mathrm{k}} & =\text { number of final parity of the cow, } \\
\mathbf{A F C}_{l} & =\text { effect of age at first calving } 1, \text { and } \\
\boldsymbol{\varepsilon}_{\mathrm{ijklm}} & =\text { random residual effects. }
\end{aligned}
$$

In addition, heritability of age at first calving was estimated using derivative-free restricted maximum likelihood method (DFREML) (Meyer, 1998) using an animal model: $\mathbf{Y}=\mathbf{X b}+\mathbf{Z a}+\mathbf{e}$, where $\mathbf{Y}$ was the vector of age at first calving records, $\mathbf{b}$ was the vector of fixed contemporary groups, a was the vector of random additive genetic effects, and $\mathbf{X}$ and $\mathbf{Z}$ were known incidence matrices relating records to fixed and random effects; respectively.

\section{RESULTS AND DISCUSSION}

The descriptive statistics for the traits described are in Table 1. Minimum and maximum of coefficients of variation (CV) among the considered traits were for age at first calving and productive life, respectively. A summary of tests of significance for the traits considered in this study is shown in Table 2. All of the factors in the models as well as age at first calving significantly affected all the traits. The estimated heritability of age at first calving was 0.086 , indicating that age at first calving has a low heritability like the other reproductive traits (Edriss and Vatan-khah, 1998). Further, this kind of trait (traits with low heritability) is highly influenced by environmental factors.

The frequency of heifers calving at different ages is presented in Figure 1. Mean age at first calving of this

Table 1. Descriptive statistics.

\begin{tabular}{lcccccc}
\hline Trait & $\mathrm{N}$ & Mean & $\mathrm{SD}$ & Min & Max & CV \\
\hline Milk yield (kg) & 12,082 & 6427.6 & 1357.3 & 1639 & $11,189.4$ & 21.1 \\
Fat yield (kg) & 11,655 & 178.96 & 38.4 & 56.95 & 345.6 & 21.4 \\
\%Fat & 11,655 & 2.84 & 0.49 & 1.39 & 6.6 & 17.1 \\
Productive life (mo) & 6,933 & 30.1 & 20.7 & 0 & 122 & 68.8 \\
Lifetime (mo) & 6,933 & 57.2 & 20.6 & 22 & 150 & 36.1 \\
AFC $^{2}$ (mo) & 15,860 & 26.84 & 2.85 & 21 & 39 & 10.6 \\
\hline
\end{tabular}

\footnotetext{
${ }^{1}$ Minimum productive life for cows which died during first calving or culled before first milk recording is equal to 0 mo.

${ }^{2}$ Age at first calving.
} 
Table 2. Results of the analyses of variance of traits studied.

\begin{tabular}{|c|c|c|c|c|c|c|c|c|c|c|c|c|}
\hline \multirow[b]{2}{*}{ Variable } & \multicolumn{2}{|c|}{ Milk yield } & \multicolumn{2}{|c|}{ Fat yield } & \multicolumn{2}{|c|}{$\%$ Fat } & \multicolumn{2}{|c|}{ Lifetime } & \multicolumn{2}{|c|}{ Productive life } & \multicolumn{2}{|c|}{$\mathrm{AFC}^{1}$} \\
\hline & $\mathrm{df}$ & MS & $\mathrm{df}$ & MS & $\mathrm{df}$ & MS & $\mathrm{df}$ & MS & $\mathrm{df}$ & MS & $\mathrm{df}$ & MS \\
\hline Herd-year-season & 608 & $* * *$ & 595 & $* * *$ & 595 & $* * *$ & 549 & $* * *$ & 549 & $* * *$ & 787 & $* * *$ \\
\hline Parity & & - & & - & & - & 8 & $* * *$ & 8 & $* * *$ & & - \\
\hline Sire & 347 & $* * *$ & 347 & $* * *$ & 347 & $* * *$ & 289 & $*$ & 289 & $*$ & 378 & $* * *$ \\
\hline Error & 9442 & 1345064 & 9017 & 896.8 & 9017 & 0.147 & 4654 & 51.95 & 4654 & 51.95 & 12269 & 52617.3 \\
\hline
\end{tabular}

\footnotetext{
${ }^{1}$ Age at first calving.

$* P<0.05$.

$* * P<0.01$.

$* * * P<0.001$.
}

population ( $26.8 \mathrm{mo}$ ) was greater than the estimated mean of 25.9 mo in the United States (Heinrichs et al., 1994) and the estimate of 26 mo in Italy (Pirlo, 1997), and less than the estimated mean of 28.6 mo in Spain (Perez et al., 1999).

Effect of age at first calving on first-lactation milk yield is shown in Figure 2. By increasing age at first calving from 21 to $24 \mathrm{mo}$, milk yield increased, but with delayed onset of first lactations more than 24 mo of age, milk yield decreased. In general, a slight negative phenotypic correlation was obtained between age at first calving and first-lactation milk yield in this study (Table 3).

Our detected negative phenotypic correlation is in contrast with other reports (Lee, 1976; Moore et al., 1991; Pirlo et al., 2000) that reported positive effects of delayed age at first calving on milk yield, In contrast, our results are consistent with those of Bewley et al. (2001), who reported a negative effect of increasing age at first calving on milk yield. They also reported that a 1-mo increase in average age at first calving was associated with $102.5-\mathrm{kg}$ reduction in milk yield

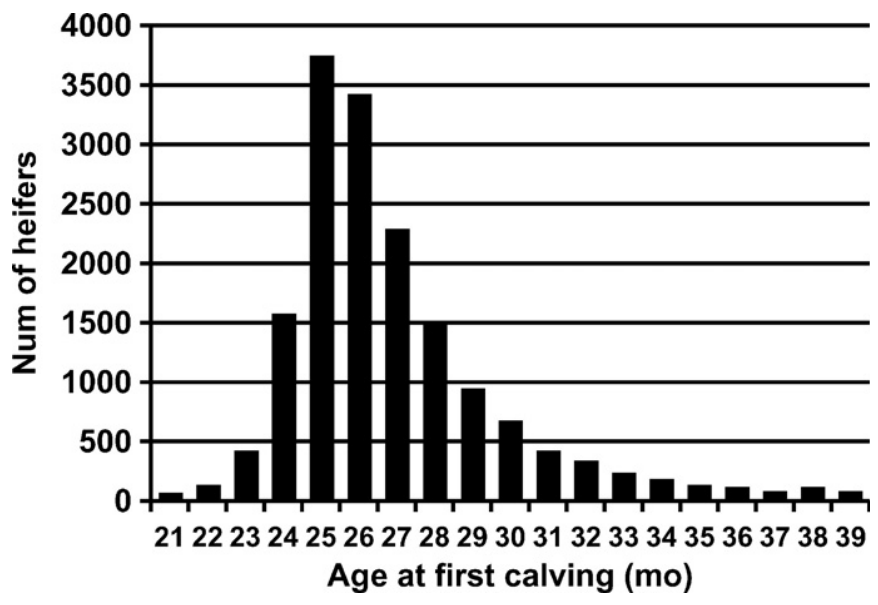

Figure 1. Frequency of age at first calving. and a reduction by one standard deviation of age at first calving was associated with a reduction of 184.6 $\mathrm{kg}$ in milk yield. Losinger and Heinrichs (1996) demonstrated production to be lower when age at first calving is greater than $27 \mathrm{mo}$ and concluded that time to breed heifers should be based on BW rather than age.

Mourits et al. (1997) concluded that the optimal milk yield of Holstein heifers occurred when the post calving body weight was between 544.2 and $566.9 \mathrm{~kg}$. A combined feeding and breeding management program is necessary for optimal results (Gardner et al., 1988). We could not consider the effect of BW on yield traits because no information was available on the population basis. A negative effect of early calving on milk yield was obtained in our study and may be due to insufficiently developed heifers. But the decrease in milk yield in late-bred heifers may be due to other factors correlated with age. Further, it seems that mammary development was diminished in late-bred heifers.

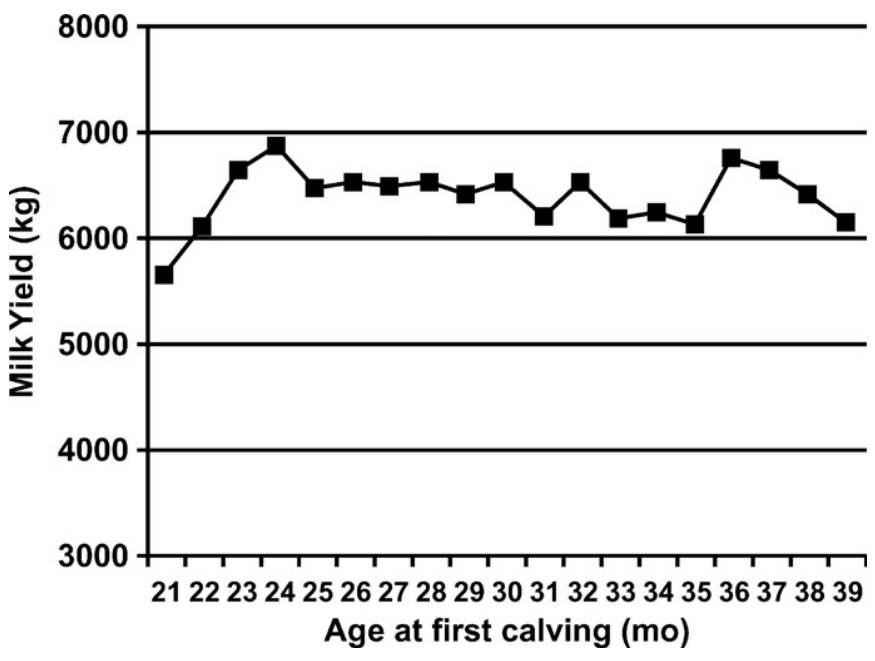

Figure 2. Effect of age at first calving on first-lactation milk yield. 
Table 3. Phenotypic correlations among the traits in this study. ${ }^{1}$

\begin{tabular}{|c|c|c|c|c|c|}
\hline Trait & $\mathrm{AFC}^{2}$ & $\begin{array}{l}\text { Productive } \\
\text { life }\end{array}$ & Lifetime & $\begin{array}{l}\text { Fat } \\
\text { yield }\end{array}$ & $\begin{array}{l}\text { Milk } \\
\text { yield }\end{array}$ \\
\hline Productive life (mo) & -0.093 & & & & \\
\hline Lifetime (mo) & 0.052 & 0.989 & & & \\
\hline Fat yield (kg) & -0.034 & 0.143 & 0.143 & & \\
\hline Milk yield (kg) & -0.089 & 0.267 & 0.261 & 0.71 & \\
\hline$\%$ Fat & 0.055 & -0.217 & -0.21 & 0.307 & -0.424 \\
\hline
\end{tabular}

${ }^{1}$ All the correlation coefficients were significant at $(P<0.001)$.

${ }^{2}$ Age at first calving.

Effect of age at first calving on first-lactation fat yield is presented in Figure 3. Fat yield increased as calving age increased to 24 mo of age, but after 24 mo of age, fat yield decreased slightly. In general, a slight negative phenotypic correlation was detected between fat yield and age at first calving (Table 3).

Because optimal age at first calving for milk yield was $24 \mathrm{mo}$, and delaying age at first calving is not cost effective, it is recommended that heifers calve between 23 and 25 mo of age (preferably 24 mo). Pirlo et al. (2000) considered the effect of age at first calving on the difference between milk yield returns and rearing costs and found that reducing age at first calving to $<26$ mo of age had a positive effect on the difference between milk yield returns and rearing costs per heifer. Reducing age at first calving to 23 and 24 mo seemed to be more profitable than reducing age at first calving to $22 \mathrm{mo}$, because the range with the largest positive difference between milk yield returns and rearing costs was between 23 and 24 mo. Only low milk prices and high rearing costs made a further reduction in age at first calving to 22 mo more profitable, but possible biological limitations of poorly developed heifers must be considered (Pirlo et al., 2000).

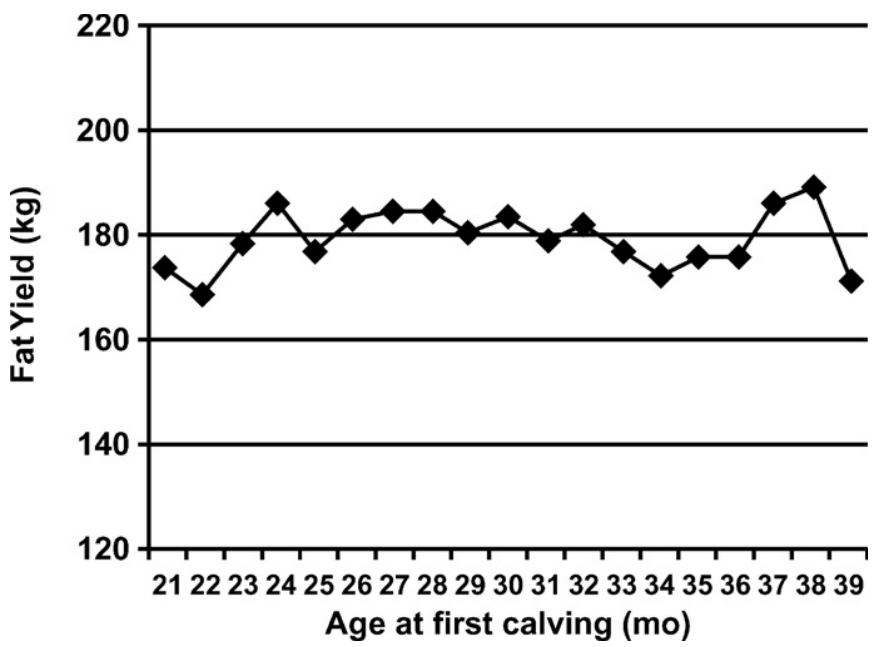

Figure 3. Effect of age at first calving on first-lactation fat yield.

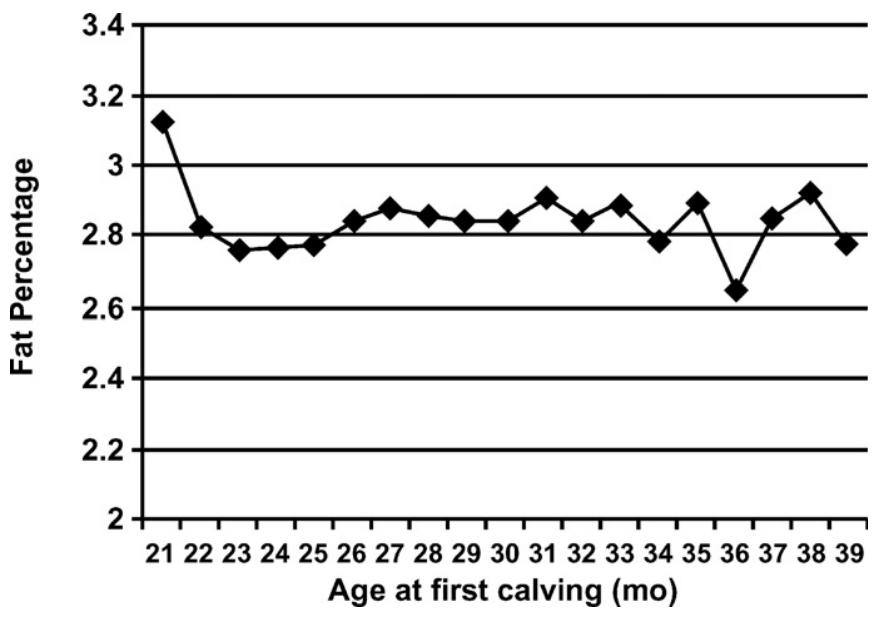

Figure 4. Effect of age at first calving on first-lactation fat percentage.

Effect of age at first calving on first-lactation fat percentage is presented in Figure 4. From calving at 21 to 23 mo of age, fat percentage decreases and then slightly increased. But similar to the trends for milk and fat yield (Figures 2 and 3 ) for heifers first calving at older ages, this trend became irregular, probably because fewer records were available in these ages. In general, a slightly positive phenotypic correlation $(0.055)$ was detected between age at first calving and fat percentage (Table 3). Harville and Henderson (1966) obtained correlations ranging from 0 to 0.11 between age at first calving and fat percentage, whereas Pirlo et al. (2000) reported reduced age at first calving seemed to have a negative effect on firstlactation fat percentages.

On average, cows in this study had $30.1 \pm 20.7$ mo of productive life during $2.6 \pm 1.5$ lactations, which is less than $1236 \pm 593 \mathrm{~d}$ or $40.7 \pm 19.5$ mo of productive life and $3.3 \pm 1.5$ lactations obtained in Spain (Perez et al., 1999). Average number of lactations and productive life obtained from the current study are relatively low, indicating that more effort and attention should be made to improve productive life in Iranian Holsteins in the Isfahan province.

The relationships between age at first calving, lifetime, and productive life are presented in Figure 5. As age at first calving increased, productive life decreased. This trend shows the importance of reducing age at first calving, which is supported by the negative phenotypic correlation $(-0.093)$ between age at first calving and productive life obtained in our study (Table 3). Lifetime did not show a similar trend for age at first calving, but most of the changes in lifetime are influenced by changes in productive life. Therefore, lifetime is greatly affected by productive life. In addi- 


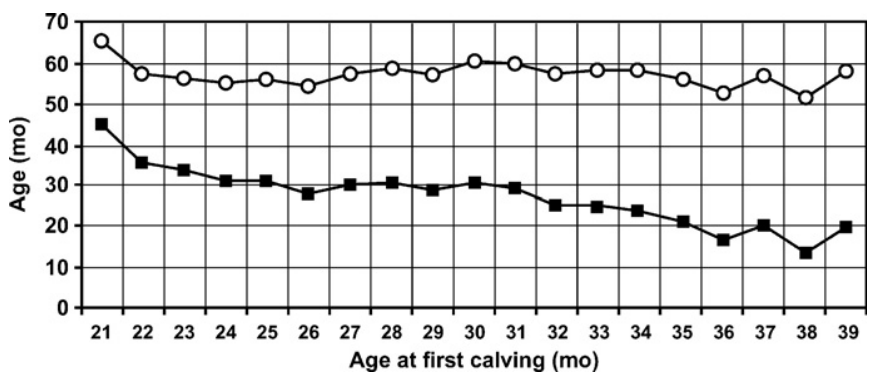

Figure 5. Relationship between age at first calving, productive life (closed squares), and lifetime (open circles).

tion, as shown in Table 3, the phenotypic correlation between lifetime and productive life (0.989) is much greater than the phenotypic correlation between lifetime and age at first calving (0.052). These 2 positive phenotypic correlations are reasonable, because lifetime is composed of age at first calving and productive life. In contrast, Gill and Allaire (1976) reported that age at first calving can affect lifetime and found a negative correlation $(-0.15)$ between age at first calving and total lifetime.

Another consideration is that after 30 mo of age at first calving, the age at first calving becomes greater than the average productive life. So, on average, as age at first calving increased from $30 \mathrm{mo}$, the time of no income for cows (from weaning to calving) will be greater than the productive life of the cows. This could be because cows with later ages at first calving have more reproductive problems, and less milk yield and fat yield (as found in present study), and, therefore, they have more culling risk and less productive life.

Lin et al. (1988) studied 2 groups of early and late breeding (subsequently early and late calving) heifers in Canada, and reported that these 2 breeding-age groups did not differ significantly in herd life. However, productive life from first calving up to $61 \mathrm{mo}$ of age in life was longer for early-bred heifers than for late-bred heifers ( 730 vs. $623 \mathrm{~d}$ ), and early calved heifers produced more total milk (10,693 vs. $9218 \mathrm{~kg}$ ) during $61 \mathrm{mo}$, and yielded more milk per day of 61-mo herd life $(6.8$ vs. $5.9 \mathrm{~kg})$. They concluded that the latebred heifers had slightly better first-lactation performances than the early-bred heifers. However, these advantages were not carried over to second and third lactations.

\section{CONCLUSIONS}

Sire was a significant source of variation for all of the traits investigated, indicating that estimating the sire EBV for selection of top bulls, could lead to genetic improvement. Reducing age at first calving is an effective strategy for dairy farmers to reduce costs. Age at first calving can significantly affect milk yield, fat yield, fat percentage, lifetime, and productive life.

Because of high rearing costs for heifers, reducing age at first calving could be very profitable to the extent that it does not harm reproductive efficiency. It seems that reducing age at first calving to 23 to $24 \mathrm{mo}$ is more profitable than reducing age at first calving to 21 to 22 mo.

Because of high and multi-dimensional benefits due to reducing age at first calving and considering existing limitations, proper modification of rearing programs need to accommodate early calving in order to reap maximum benefits.

\section{ACKNOWLEDGMENTS}

Financial support of Isfahan University of Technology (project AGA812) is acknowledged.

\section{REFERENCES}

Bewley, J., R. W. Palmer, and D. B. Jackson-Smith. 2001. Modeling milk production and labor efficiency in modernized Wisconsin dairy herds. J. Dairy Sci. 84:705-716.

Dematawewa, C. M. B., and P. J. Berger. 1998. Genetic and phenotypic parameters for 305-day yield, fertility, and survival in Holsteins. J. Dairy Sci.81:2700-2709.

Donovan, G. A., L. Badinga, R. J. Collier, C. J. Wilcox, and R. K. Braun. 1986. Factors influencing passive transfer in dairy calves. J. Dairy Sci. 69:754-759.

Edriss, M. A., and M. Vatan-khah. 1998. Genetics and Dairy Cow Breeding. Arkan Press, Iran.

Gardner, R. W., L. W. Smith, and R. L. Park. 1988. Feeding and management of dairy heifers for optimal lifetime productivity. J. Dairy Sci. 71:996-999.

Gill, G. S., and F. R. Allaire.1976. Relationship of age at first calving, days open, days dry, and herd life to a profit function for dairy cattle. J. Dairy Sci. 59:1131-1139.

Harville, D. A., and C. R. Henderson. 1966. Interrelationships among age, body weight, and production traits during first lactation of dairy cattle. J. Dairy Sci. 49:1254-1261.

Heinrichs, A. J. 1993. Raising dairy replacement to meet the need of the 21st century. J. Dairy Sci. 76:3179-3187.

Heinrichs, A. J., S. J. Wells, H. S. Hurd, G. W. Hill, and D. A. Dargatz. 1994. The national dairy heifers evaluation project: A profile of heifer management practices in United States. J. Dairy Sci. 77:1548-1555.

Lee, A. J. 1976. Relationship between milk yield and age at first calving in first lactation. J. Dairy Sci.59:1794-1801.

Lin, C. Y., A. J. McAllister, T. R. Batra, and A. J. Lee. 1988. Effects of early and late breeding of heifers on multiple lactation performance of dairy cows. J. Dairy Sci. 71:2735-2743.

Losinger, W. C., and A. J. Heinrichs. 1996. Dairy operation management practices and herd milk production. J. Dairy Sci. 79:506-514.

Martinez, M. L., A. E. Freeman, and P. J. Berger. 1983. Genetic relationship between calf livability and calving difficulty of Holsteins. J. Dairy Sci. 66:1494-1502.

Meyer, K. 1998. DFREML: Programs to estimate variance components by restricted maximum likelihood using a derivative-free algorithm. User notes, Version 3.0 $\beta$. University of New England, Armidale, Australia. 
Moore, R. K., B. W. Kennedy, L. R. Schaeffer, and J. E. Moxley. 1991. Relationships between age and body weight at calving and production in first lactation Ayrshires and Holsteins. J. Dairy Sci. 74:269-278.

Mourits, M. C. M., A. A. Dijkhuizen, R. B. M. Hurine, and D. T. Galligan. 1997. Technical and economic models to support heifer management decisions: basic concepts. J. Dairy Sci. 80:14061415.

Perez, M. A., D. Hernandez, R. Alenda, M. J. Carabano, and N. Charfeddine.1999. Genetic analysis of true profit for Spanish dairy cattle. Address: www.interbull.slu.se/bulletins/bulletin23/perez.pdf.

Pirlo, G. 1997. Rearing cost of replacement heifer and optimal age at first calving. Suppl. L Informatore Agrario 37:9-12.
Pirlo, G., F. Miglior, and M. Speroni. 2000. Effect of age at first calving on production traits and on difference between milk yield returns and rearing costs in Italian Holsteins. J. Dairy Sci. 83:603-608.

Simerl, N. A., C. J. Wilcox, W. W. Thatcher, and F. G. Martin. 1991. Prepartum and peripartum reproductive performance of dairy heifers freshening at young ages. J. Dairy Sci. 74:1724-1729.

Thompson, J. R., E. J. Pollak, and P. L. Pellisier. 1983. Interrelationship of parturition problems, production of subsequent lactation, reproduction, and age at first calving. J. Dairy Sci. 66:11191127.

Vukasinovich, N., J. Moll, and L. Casanova. 2001. Implementation of a routine genetic evaluation for longevity based on survival analysis techniques in dairy cattle populations in Switzerland. J. Dairy Sci. 84:2073-2080. 